\title{
Searching for Low Cost Alternative Energy Source: An Analysis of Pakistan Sugar Industry
}

\author{
Manzoor Hussain Memon ${ }^{1} \nless$ \\ Nadeem Ahmed ${ }^{2}$ \\ Engr. Raja Masood Larik ${ }^{3}$ \\ 'PhD Scholar / Candidate, Applied Economics Research Center, University of Karachi, Karachi \\ Email:manzoorhmemon@yahoo.com \\ ${ }^{2}$ Social Policy Advisor, SDGs Support Unit, Ministry of Planning Development and Reform, Government of \\ Pakistan \\ Email:nadeem.ahmed@undp.org; nadeem65ah@gmail.com \\ ${ }^{s}$ PhD Research Candidate, Faculty of Electrical Engineering, Universiti Teknologi, Malaysia \\ Email:rmlarik@gmail.com
}

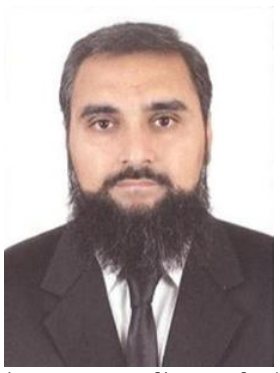

Corresponding Author)

\begin{abstract}
Pakistan is searching for alternative energy sources owing to perpetual power crisis in the country. Stylized facts suggest that there is a strong correlation between energy consumption and economic growth, while more economic activity leads to more employment and contributes to reduce poverty. Supply dynamics considered as major cause of energy crisis in Pakistan. Sugar industry in Pakistan is assumed as an opportunity and potential for alternative energy production. This paper is an attempt to explore the alternative source of energy generation by using latent potential of sugar industry and explore the possibility of having surplus production and generation of electricity for national grid. Bagasse, a residual by-product from sugarcane is traditionally used for generation of electricity in the industry to meet its own energy needs. In addition to the analysis of potentiality of the industry, the economic analysis is also carried out from the perspective of foreign exchange saving that have been used to import furnace oil for power generation. From the retrospective analysis, it is revealed that country could save minimum 242 million dollars during the sugar season that is almost one fourth of the total furnace oil import of the country during the same period.
\end{abstract}

Keywords: Economic growth, Sugarcane, Electricity, Energy, Alternative energy sources.

JEL Classification: $\mathrm{O} 4, \mathrm{Q} 4, \mathrm{Q} 42$.

Citation | Manzoor Hussain Memon; Nadeem Ahmed; Raja Masood Larik (2017). Searching for Low Cost Alternative Energy Source: An Analysis of Pakistan Sugar Industry. Growth, 4(1): 1-10. History:

Received: 5 December 2017

Received. 5 December 2017

Accepted: 22 December 2017

Published: 29 December 2017

Licensed: This work is licensed under a Creative Commons

Attribution 3.0 License (cc) EY

Publisher:Asian Online Journal Publishing Group
Contribution/Acknowledgement: All authors contributed to the conception and design of the study.

Funding: This study received no specific financial support.

Competing Interests: The authors declare that they have no conflict of interests.

Transparency: The authors confirm that the manuscript is an honest, accurate, and transparent account of the study was reported; that no vital features of the study have been omitted; and that any discrepancies from the study as planned have been explained.

Ethical: This study follows all ethical practices during writing.

\section{Contents}

1. Introduction

2. Review of Selected Literature

3. Energy Crisis and the Energy Mix

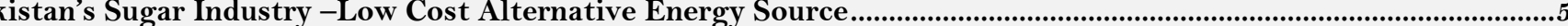

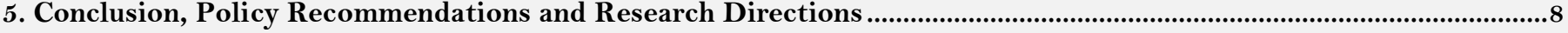

References..

Footnote 


\section{Introduction}

Energy crisis is the most pressing issue for almost all the countries in the world. Ironically, no single country could resolve this issue keeping in view the changing global energy situation. Perpetual instability of global oil prices has directly impacted the energy supply that paved the way of policy options for alternative energy resources. The option of nuclear energy is not viable due to recent incidence in Japan where nuclear installation effected from earthquake. Energy generation from coal is also not feasible from environmental viewpoint. The higher dependence on oil for energy generation and absence of viable alternative options turned energy crisis a critical global issue.

The energy crisis has deeply rooted in the oil crisis of early 1970s, when there was an increase of a factor of five from 2 US\$ per barrel to 10 US\$ per barrel. ${ }^{1}$ At global level, the search of viable alternative sources of energy was realized at the outset of crisis. The continuous increase in the oil prices has hampered global development process especially in developing countries. As a result, oil prices were above in the cost of living curves in late 1970 s and early 1980s. ${ }^{2}$ Global response lacked coordinated efforts to overcome the emerging crisis. Developing countries lacked motivation largely because of the absence of necessary capital resources. It is now imperative for developing countries to manage its existing energy resources efficiently along with exploring alternative sources to meet short-term as well as long-term energy demand.

No one could deny or ignore the significance of energy for intensive technological and industrialization production and distribution processes that is considered as an embodiment of development and growth. Rapid industrialization and improved technological processes have significantly increased the economics activities thus higher growth rates. With high growth of population and increased economic activities, the demand of various economic and non-economic services has increased that resulted in the higher demand of energy. Technological revolution on the other hand, incessantly changed altruist human culture and life to a modern and competitive "energy intensive culture". It is commonly believed that higher economic growth is often correlated with the higher energy consumption as industrialized countries have higher per capita GDP due to higher per capita energy consumption.

In developing countries, millions of people are facing various difficulties and challenges due to unavailability of energy resources that could compromise growth for future generations. The lower end of energy consumption in developing countries also impeded growth of large scale industrialization. ${ }^{3}$ To sustain higher growth and expansion in economy, it is essential to guarantee uninterrupted supply of energy to all sectors of the economy. Hence, one of the major concerns of developing countries to maintain higher energy supplies to meet the increasing demand.

Since the very beginning, Pakistan has been experiencing crisis in the energy sector. The sector has passed through difficult phases as issues and shortcomings surrounded this sector immensely. ${ }^{4}$ Over the years, energy requirements were increased rapidly and have witnessed a significant upward shift. In turn, the crisis has adversely affected the growth and development of the economy which resulted in poverty and destitute for millions of people. According to National Academy Press (1986) electricity, productivity and the volume of GDP have strong correlation between them. ${ }^{5}$ Pakistan along with other developing countries failed to manage existing resources as well as to explore the alternative energy potentials for its development needs. No serious effort has been made in last 50 years and the development of renewable and alternative energy resources in Pakistan are still at infancy stage.

\section{Review of Selected Literature}

Ample evidence is found in literature that highlighted the importance of energy for economic growth. However, most of the literature largely covers the traditional sources of energy production and its consumption and investigates the relationship with economic growth. Literature on alternative non-traditional sources is limited to technical viability and feasibility, and empirical work on energy from alternative non-traditional source is hardly found and particularly with reference to developing countries. This may be because in developing countries such phenomenon of energy from non-traditional alternative sources has not been explored yet. Despite the fact that such phenomenon is now more than three decades old, the research on non-traditional energy sources has been limited and found scarce in existing literature. Nonetheless, in recent studies this key important area of alternative energy has gained significant importance. The literature produced has also proved its significance for development and growth strategies. Macroeconomic growth theories mainly focus on the two traditional components of production function i.e. capital and labor; they do not attach necessary importance to other inputs i.e. power and energy, which is now being focused for growth and development (Stern and Cleveland, 2004). ${ }^{6}$ However, the literature incorporating and expanding the scope from traditional approach are very few and limited to relationship between energy and economic growth. In the similar context, few studies are found in the context of Pakistan. Similarly, studies address the emerging issues and traditional energy sources and very few studies accounts for alternative energy and its impact on growth and development. Thus, in the literature and empirical analysis on overall supply side dynamics especially for potentially for alternative source is scarce.

Mbohwas (2013) identifies the energy management and best practices approach for the effectiveness of cogeneration process in South African sugar industry. Accordingly, equipment and technological improvements were identified as necessary condition to make the energy cogeneration efficient. Mubashir and Koji (2013) identified the underutilization of installed power generation capacity as one of the major cause of energy shortage and encourage fossil fuel consumption for private electricity.

Saqlain et al. (2013) revisited the causal relationship between coal consumption (as alternative energy resource) and economic growth in Pakistan. They found bi-directional granger causality between the two major components of the study in both time scales i.e. short run and long run. The study emphasizes in the context perceived results that exploration efforts for coal as an alternative and economical source of energy should be augmented.

Shahbaz et al. (2012) in their investigation found that energy consumption add to economic growth. While, (Zeeshan, 2012) revealed that there is significant impact of higher tariff rates on the business environment in the 
country. The findings associate the high cost of thermal power generation actually erodes the private business investment in short run, thus suggest the hydropower plants to reduce the cost of energy.

Walfrido et al. (2009) studied the technical viability - the techno-economic assessment of cogeneration units of sugar industry as alternative energy carrier to country's electricity. The author analyzed the cogeneration capacity of the industry and barrier of implementation. The paper also discussed the industry's off-season capabilities to generate electricity which in many cases remained unresolved to-date. To overcome this problem, the paper discussed the importance and possibilities of bio-oil as an alternative energy carrier during off-season. The key message of the paper was that the cogeneration of energy during the season would be first step towards the feasible implementation of new thermo-conversion technologies.

Gwang'ombe (2004) in his working papers discusses the failure of African governments to respond to 10 percent renewable energy targets proposed in World Summit on Sustainable Development in 2002. The aim of working document was to investigate the biomass-based cogeneration in sugar factories in Tanzania and possibilities to enhance their capacity with required modifications. According to his findings, the annual electricity potential from the subjected alternative source is $99 \mathrm{GWh}$ (Giga Watt hour) considering the potentially of bagasse production. However, this would contribute only to an extent of 3.5 percent of the national electricity production.

Deepchand (2001) a sugar technologist, proposed that a state of the art technology has a potential of about 343 GWh of electricity generation from estimated one (1) million tons of bagasse annually. Accordingly, he estimated the annual potential of about 5,500 GWh of electricity generation from estimated 16 million tons. Based on Mauritius experiences, he also examined the potential of replication in Eastern and Southern African Region. The policy measure in the study were based on proposal for using bagasse during the season, while use of coal during the off-season for ensuring continuous power availability.

\section{Energy Crisis and the Energy Mix}

\subsection{The World}

Since the Oil crisis in 70s, the energy mix of the world has been continuously changing. As exhibit in the Figure 1 below, the energy mix in 2010 reveals the highest share of coal with 41.2 percent, followed by natural gas 21.9 percent, Hydro 15.6 percent, nuclear 11.7 percent and oil 3.9 percent. The energy from other renewable has been increasing in the last one decade and stood at approx. 4.7 percent of the total energy mix in 2010. As of 2013, the share has increased to 21.7 percent.

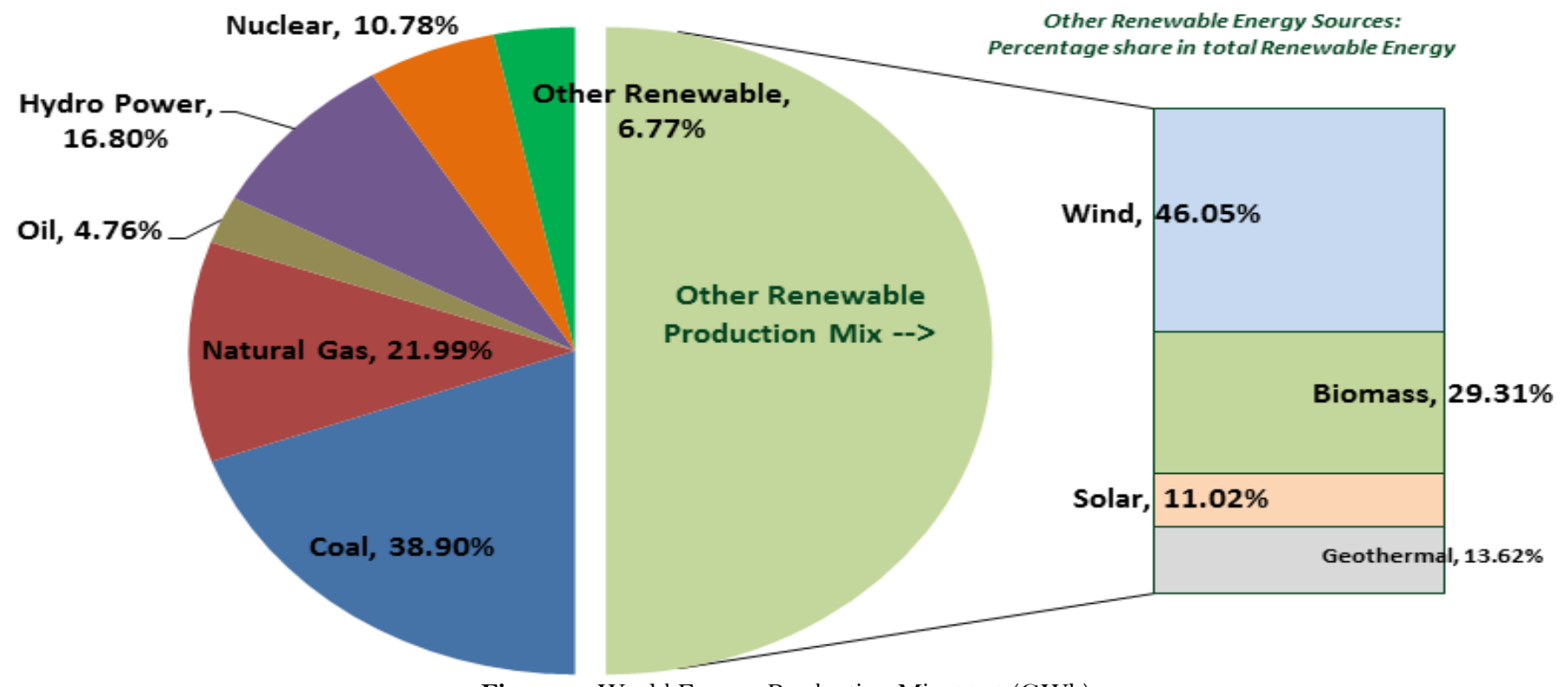

Data Source: TSP Data Portal

Figure-1. World Energy Production Mix 2014 (GWh)

http://www.tsp-data-portal.org/Breakdown-of-Electricity-Generation-by-Energy-Source\#tspOvChart

http://www.tsp-data-portal.org/Breakdown-of-Electricity-Generation-by-Energy-

Source? select=ELPRODP Unit\%2C\%22\%22GWh\%22\%22\&select=ELPRODP Year\%2C $\% 22 \% 222014 \% 22 \% 22$

Percentages calculation - Author's Own Calculation based on raw data

Wind power is the fastest growing component amidst the other alternative sources; the annual growth rate during the period 2000-2010 was over 25 percent, which reduced during the last five years however still on higher side at around 17 percent. Estimated installed capacity has increased from 17,400 megawatts in the year 2000 to 432,419 (MW). Of this, major installation can be found in Asia with $41 \%$ share, followed by Europe at $34 \%$, and North America with $21 \%$ share. About 72 percent of the installed wind energy is shared amongst the five major countries. China has the installed capacity with the 34 percent share, followed by United States of America at 17 percent, Germany at 10 percent, India at 6 percent and Spain at 5 percent. According to estimates, the renewable energy contributes more than 20 percent of the energy supply in most of the countries. ${ }^{7}$ The share of renewable energy in United States of America stood more than 10 percent in the total energy mix. 


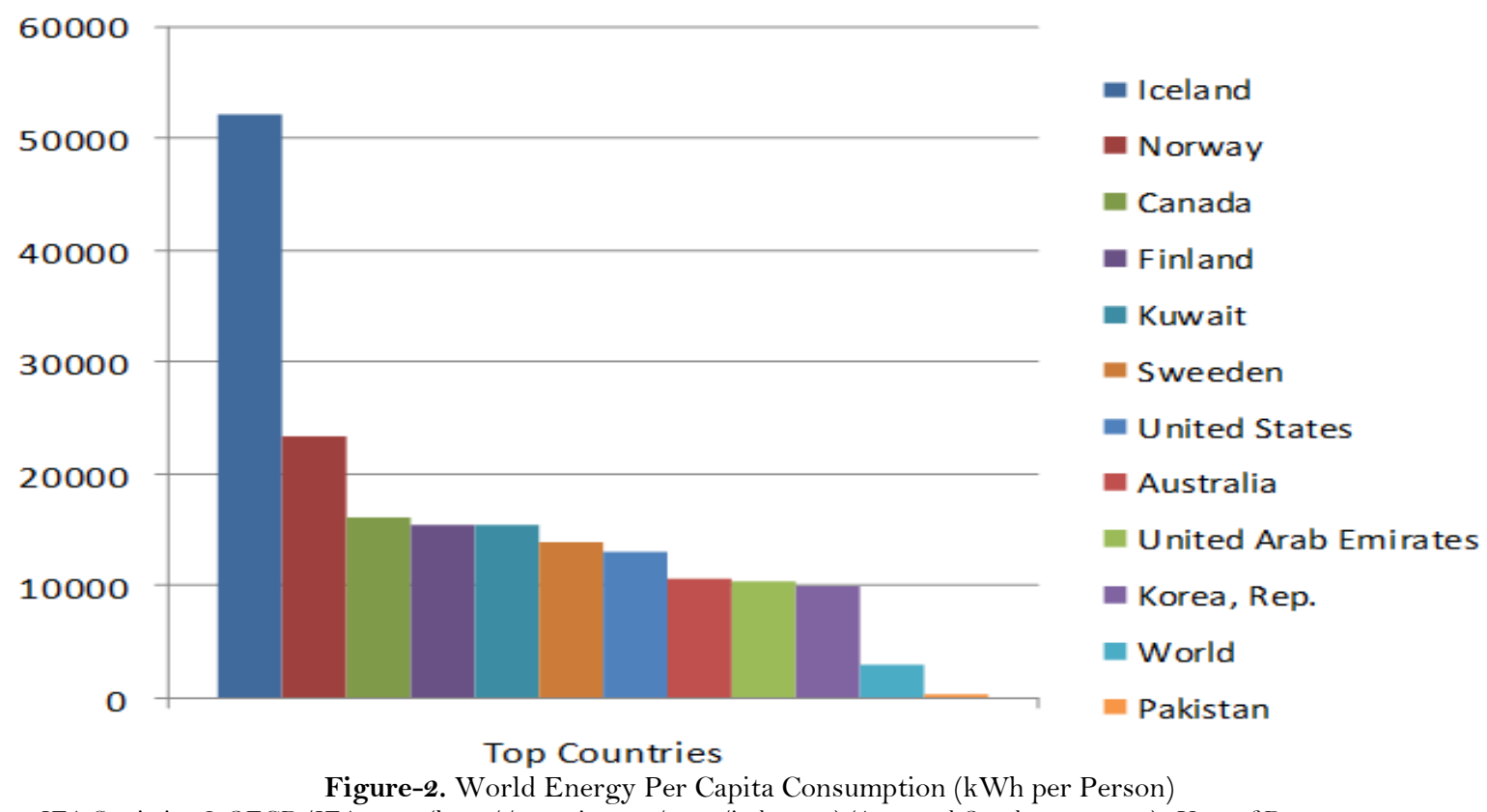

Data Source: IEA Statistics (C) OECD/IEA 2014 (http://www.iea.org/stats/index.asp) (Accessed October 20, 2014); Year of Data 2011

It can be seen from the Figure 2 that top ten countries having highest per capita energy consumption are the developed countries in the world. In terms of average power per capita (Kilo Watt hour per person) Pakistan stood at 160 th position with $457 \mathrm{kWh}$ per person as against world average of 3,013 kWh per person.

According to US agency, the world demand for all forms of energy is expected to grow by almost 50 percent over the next two decades. The electricity demand will also double by the year 2025, growing 3.5 percent per annum in developing countries, mainly due to industrialization policies and increasing demand of home appliances. The increasing demand will in turns puts the pressure on the sources of electricity generation also, reflected in high prices of oil and natural gas as an important source of generation throughout the projections.

\subsection{Energy in Pakistan}

In Asia, the robust economic growth has increased demand for electricity. With the rise in standards of living the demand for appliances such as heating and cooling, the other household appliances and electrical devices associated with have increased the demand for electricity. Pakistan along with other countries in the South Asian region emerged as a country that has potential of higher GDP growth. Accordingly, energy requirements increased rapidly from 34 million $\mathrm{TOE}^{8}$ in 1994-95 to 61 million TOE in 2009-10, witnessed an increase of 80 percent in the last one and half decade rises from. Pakistan is heavily dependent and 99 percent of energy requirements are fulfilled through on non-renewable conventional sources. ${ }^{9}$

Pakistan's unfavorable mix in energy sources and high associated cost led to a core of the energy crisis. This is mainly on the back policy measures in past shifting the power generation largely based on fuel / furnace oil because of the ever increasing price (historical perspective) of imported furnace oil as compared to hydropower plants. The lack of efficient mobilization of domestic energy resources resulted in continuation of oil import dependence. One of the key reasons behind heavy dependence on thermal power generations was mainly prioritizing the other sectors in the past such as domestic consumers, and fertilizer producers etc. ${ }^{10}$

Historically, indigenous gas and hydro power covers the major pie in the energy mix of Pakistan. The share of hydro power that accounted for 60 percent of the power generation till 1980, fell around 45 percent and 30 percent by 1990 and 2005 respectively, and remained stagnant till 2012.11 This is mainly because of untapped hydro potential of 30,000MW,12 and only about 6000MW has so far been exploited. As exhibited in figue 3, Pakistan faced a major disequilibrium in power sector for the first time during FYo6, which further increased in the subsequent years. According to Private Power and Infrastructure Board (PPIB), the country witnessed 10 percent excess capacity in 2002, has faced a surge in demand in excess of available capacity during $2005 \& 2006 .{ }^{13}$

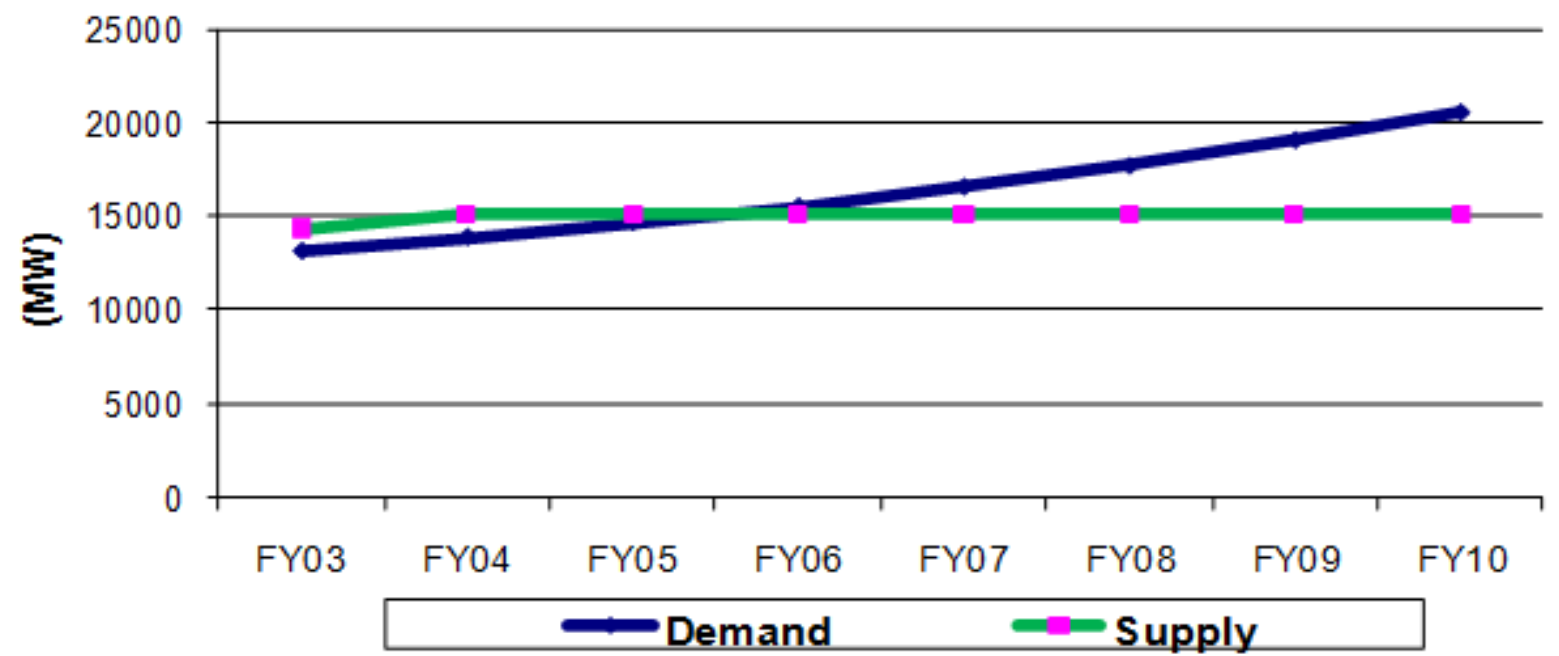

Figure-3. Demand \& Supply Gap in Pakistan

Data Source: Private Power \& Infrastructure Board (PPIB) 
The indigenous natural gas which comprises of above 50 percent in energy mix during 2005 reduced to 26 percent in 2012, while oil imports in energy mix increased to 37 percent in 2012 from 16 percent in 2005. Figure 4 exhibits the high cost unfavorable energy mix in Pakistan with increase dependence on furnace oil during 212 visà-vis 2005. The latter has increased mainly on account of increased power generation from IPPs constituting almost 53 percent of total electricity generation in energy mix of Pakistan.

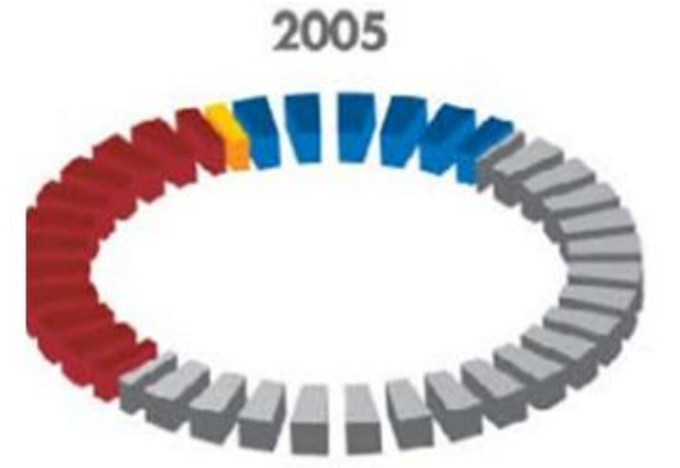

Hydel: $31 \%$ Nuclear \& Imported: $1 \%$

Iill Gas: $52 \%$

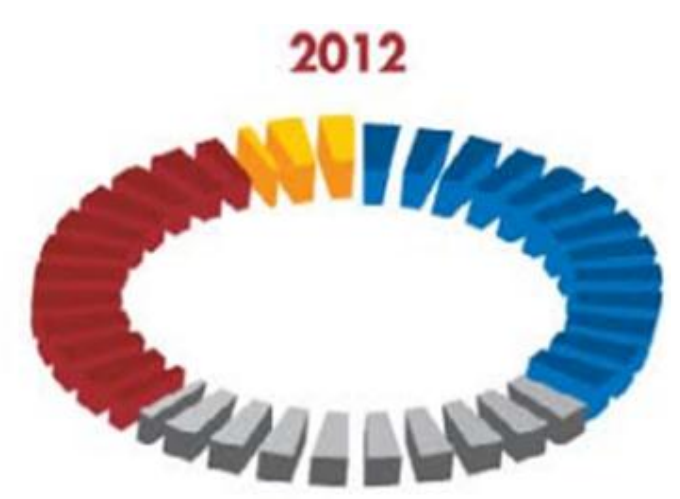

- Hydel: $31 \%$ Nuclear 8 Imported: $6 \%$ - Oil: $37 \%$ Gos: $26 \%$

Figure-4. High Cost Unfavorable Energy Mix of Pakistan

Data Source: Allied Rental Modaraba, Annual Report 2013, (http://www.arm.com.pk/pdf/annual_report_2013.pdf (Accessed October 25, 2013)

Energy crisis in Pakistan is not only about the installed generation capacity, it is mainly because of the poor management and bad governance in the sector. The installed generation capacity is $23,500 \mathrm{MW}$, however, only $60 \%$ of the capacity is available because of the several reasons including the bad governance and the large dependence on high cost Oil. This has further led to growth in oil consumption in Pakistan, grown at a rate of 4.7 percent per annum since 1980.14 Oil consumption for power generation exhibits an average growth of 8 percent during the period 1990 to 2012 . The oil and oil based imports in 2014 accounts for almost 33 percent of the total imports, equalized almost 60 percent of the merchandise exports earning in 2014. ${ }^{15}$ Such high substitution of oil imports with the merchandising exports assumed to be highly unfavourable for the economy.

Pakistan is among those developing countries where the need to tackle the challenge of growing demand of electricity is greatest. Due to higher economic growth during the period 2001-2007, there is a growing demand for energy in Pakistan and expected to keep on raising in subsequent years. Despite this, per capita power consumption is far below at 15 percent of the total world average per capita consumption. ${ }^{16}$ According to National Electric Power Regulatory Authority (NEPRA), the average cost of 1 KWh of electricity through Furnace Oil is Rs. 14.84 and High Speed Diesel is Rs. 18.31 in 2011. ${ }^{17}$ The supply of the energy at affordable price also poses challenge to authorities. Therefore, it is highly needed at the time to fill the gap between the growing demand and supply of energy through low cost sources which include hydro, biomass, solar and wind energy.

Pakistan is rich in natural gas resources but its management is poor. Adoption of cost and production efficiency technologies in the sector are much needed. Beside this, to cope up with ever growing energy crisis, effective measures and policy incentives should be given for generation of energy through alternative and renewable resources. ${ }^{18}$

\section{Pakistan’s Sugar Industry -Low Cost Alternative Energy Source}

Sugar Industry is the only agro-based industry in the rural areas that drives the rural economy in the larger context. ${ }^{19}$ While Sugarcane a major raw material for the industry, is an important cash crop. Thus both the industry and the agri-produce are termed as vehicle of development in rural economy.

Sugarcane, beside its natural sugar content also produces molasses and left crushed bagasse - a fibrous material as by-products. The former by-product is further used to produce soda and ethanol, while the bagasse is burned in the boilers to produce heat and electricity. Bagasse is also be used as raw material for paper, cardboard, and eating utensils. $^{20}$ Bagasse has always been the major, if not the only, source of combustible in sugarcane producing countries worldwide to meet the energy requirement to process cane into sugar and the by-products. ${ }^{21}$ Burning the bagasse for energy generation is beneficial to the environment, given that this energy would have otherwise been produced from greenhouse producing fossil fuel. ${ }^{22}$

\subsection{Key Features of Sugar Industry in Pakistan}

Sugar industry in Pakistan began its journey with the inheritance of two sugar mills having installed capacity sufficient for only 6 percent of the total domestic demand. The burden has reduced over time to a just selfsufficiency by early and mid 90s. Pakistan Industrial Development Corporation (PIDC) has played a key role the development of the sector. The industrialization and domestic manufacturing of primary and moderate technology is also motivating factor behind domestic investment in the sector. However, despite the just self-sufficiency, the country has been facing the sustainability in self-sufficiency mainly on account of poor agricultural policies. ${ }^{23}$ 


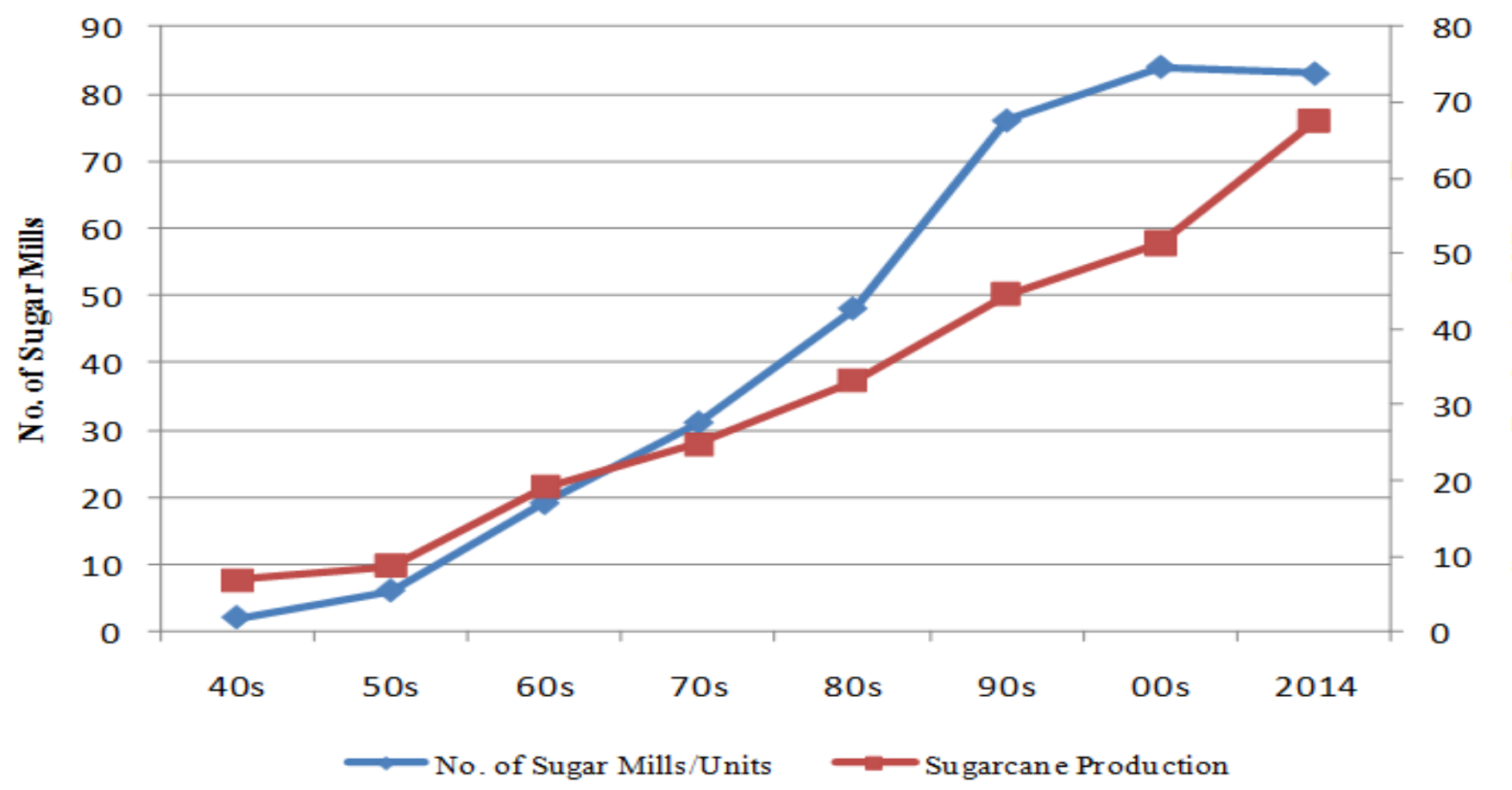

Figure-5. Historic Growth in Sugar Industry \& Sugarcane Production

Data Source: Pakistan Sugar Mills Association: http://www.psmacentre.com/statistics.php?stid=1\&type=national\&status=1 (Accessed October 20, 2014); Manzoor H Memon, “Sugar Industry: Sector Update - March 2010”, JCR-VIS Credit Rating Co. Limited (2011)

As exhibited in the Figure 5, most rapid growth was observed during the period of 1990s mainly on account of liberalization, and easy credit policies translated into conditions conducive to private investment. As of to-date, more than 80 units are operating with capacity to produce over 6.5 million metric ton (MMT) of sugar per annum. This is against the existing consumption pattern and demand of 4.3MMT per annum, thus the residual reflects the export potential. The average sugar content ranges from 8.0 percent to 9.0 percent across the country, with exceptional recovery rates in some region to over 11 percent. As of 2011-12, the estimated crushing capacity approached 500,000MT per day ${ }^{24}$, exhibiting total crushing capacity of over 70MMT per annum. ${ }^{25}$

In recent year, the industry has tried to optimize its function along with the cogeneration for surplus electricity to supply national grid. Overall, technological progress over time in the industry have been very slow mainly attributed to fluctuations in sugar production, underutilization of capacity, stagnant recovery rates and other nonattractive policies for electricity generation.

\subsection{Low Cost Alternative Energy Potential}

Sugarcane is also considered as a potential energy crop in addition to a food crop. Since the development of Bio-mass renewable energy sources, sugarcane has gained great importance. This is because of its energy security implications which are a result of its renewable nature and also the economic benefits it offers to the sugar industry. ${ }^{26}$ The sugar industry in the world has experienced significant growth due to its capability to produce food as well as energy. While oil prices are soaring in world market, the relatively low cost energy produced in the form of bio-ethanol and electricity are the major reasons behind such growth in the sector.

With the advancement in cogeneration technologies, the potential of cogeneration stood around 88,500 GWh. Estimates show that most of Sub Saharan African countries have potential to meet a significant proportion of current electricity consumption from the industry. It is also revealed that around 20 percent of total energy mix in the Mauritius is contributed from cogeneration technologies. ${ }^{27}$ The phenomenon of generating surplus electricity is not new, Mauritius sugar sector is generating bagasse based surplus electricity since 1970. ${ }^{28}$

Analysis revealed that contribution from bio-energy in the total energy mix has been increasing. About $20 \%$ of the total energy mix in United States of America is from the bio-energy installations. Bio-mass energy is the third most contribution in the total energy mix of the Brazil. The sugarcane industry in Brazil supplies the surplus electricity from bagasse cogeneration to national grid. Japan and Germany also paying heed to this inevitable technique (World Energy Resources and Consumptions). According to estimates, India has the potential of biomass co-generation particularly from the sugarcane is $5000 \mathrm{MW}$. The relatively higher contribution of sugar industry in the total energy mix is 10 percent in Nicaragua (the country in Central America). ${ }^{29}$ In Indonesia, potential generation capacity by sugar mill stood around 79,248 MWh, of which off season capacity stood at 35,910 MWh. ${ }^{30}$

The bagasse produced after the juice extraction from crushing of sugarcane is considered enough to power the selective mill operations. With efficient technology, the left over is estimated at the rate of 30 percent i.e. 10 metric tons of sugarcane produces almost 3 tons of we bagasse. ${ }^{31}$

Sugar industry produces from 2500 - $300 \mathrm{~kg}^{32}$ of bagasse - a solid residue from a ton of sugarcane crushed. In Pakistan, based on current industrial capacity, there has been estimated potential of about $3000 \mathrm{MW}^{3 s}$ that accounts for almost 9 percent of the total installed generation capacity from traditional resources. This can potentially generate over $7000 \mathrm{GWh}^{34}$ of electricity in the sugar crushing season annually subject to state-of-the art technology and availability of required bagasse. The advanced cogeneration capacity of the industry has allowed not only meeting the auxiliary requirement (for generation and cane crushing) of the industry but also producing surplus to supply to national grid directly. Bagasse is the by-product of 30 percent residue of sugarcane that shows current potential at about 16 million tones. Based on these estimates, industry can generate over $700 \mathrm{MW}$ of electricity translating in to approximately $1680 \mathrm{GWh}$ of generation during sugar crashing season. ${ }^{35}$ 
During the period 2004-2014, the average sugarcane production stood at around 55MMT, accounts for only 75 percent of the total industry's crushing capacity in the season. At optimum capacity, the industry can produce $21 \mathrm{MMT}$ of baggase which can produce about $875 \mathrm{MW}$ of electricity, translate into $2100 \mathrm{GWh}$ of electricity during the season. ${ }^{36}$ Despite this, the current available raw material at its optimum level only translates in to 30 percent of the energy vis-à-vis the total potential of the industry. Table 1 below exhibits the bagasse production and electricity generation potential during the season.

Table-1. Current Production Scenarios with Potential Availability of Raw Material

\begin{tabular}{c|c|c|c|c}
\hline Scenarios & $\begin{array}{c}\text { Crushing } \\
\text { MMT }\end{array}$ & $\begin{array}{c}\text { Bagasse } \\
\text { Generation } \\
\text { MMT }\end{array}$ & $\begin{array}{c}\text { Electricity } \\
\text { Generation } \\
\text { MW }\end{array}$ & $\begin{array}{c}\text { Electricity } \\
\text { Production Hours } \\
\text { MWh }\end{array}$ \\
\hline $\begin{array}{c}\text { Scenario 1 } \\
\text { Capacity Utilization @ 60\% }\end{array}$ & $42 \mathrm{MMT}$ & $12.6 \mathrm{MMT}$ & $525 \mathrm{MW}$ & $1260000 \mathrm{MWh}$ \\
\hline $\begin{array}{c}\text { Scenario 2 } \\
\text { Capacity Utilization @ 80\% }\end{array}$ & $56 \mathrm{MMT}$ & $16.8 \mathrm{MMT}$ & $700 \mathrm{MW}$ & $1680000 \mathrm{MWh}$ \\
\hline $\begin{array}{c}\text { Scenario 3 } \\
\text { Capacity Utilization 100\% }\end{array}$ & $70 \mathrm{MMT}$ & $21 \mathrm{MMT}$ & $875 \mathrm{MW}$ & $21000000 \mathrm{MWh}$ \\
\hline
\end{tabular}

Sugarcane Crushing Season 120-160 days

Based on discounted 100 days of Generation in relation to $120-160$ operational days

Major limiting factor of the industry is the seasonal supply of electricity to national grid. Discounting with the peak period, the sugar industry can supply electricity for a period of 100 days only out of its operational period of 120-160 days. However, this limitation can be overcome by installing dual fires plants using coal or other biomass or crop residuals like rice husk from rice mills, wood waste from wood conversion industries, empty fruit brunch, corn cob, other special agri-produce such as Manjhandri etc. as substituting fuel. Manjhandri is a special crop grown in Sindh province and used from chip board making. With the use of other bio-mass and available options, the supply can increase by three fold to its optimum potential during the season, while making the supply viable and feasible during the off-season. Nonetheless, considering the impact of crisis on country's GDP and to address the shortcomings in the short run, the importance of sugar industry based electricity cannot be ignored. However, a research is needed to explore the possibilities of substitution of fuel for electricity production in sugar industry.

Bringing the sugar sector in the energy mix would not only increase the size of the total energy mix but also bring in diversification by adding a slice in the overall energy pie. This also have multiplier effect on the economy. The energy potential can attract both domestic and foreign investments in the sector and the associated primary sectors specifically the agriculture sector. Import of bagasse and other bio-mass can also be suitable option for the industry to smoothen the energy supply both in the season and off-season. This can also optimize the energy potential of the industry.

One third of Pakistan's imports are in the form of oil and oil products value over 12 billion dollars in 2012-13. Of this, furnace oil accounts for 29 percent of the total imports. Power sector is the second largest consumer of oil/petroleum after transport sector, together accounts for 90.4 percent of the total oil imports in the country. With economic stabilization after financial and economic crises, oil prices are expected to rise considerably in coming years. The current level of oil imports are projected to increase by 300 percent in the next few years largely due to anticipated increase in oil prices. ${ }^{37}$ Therefore, there is a need to address the issue by substituting the conventional energy forms with non-conventional alternative sources of energy. As in 2011, the average cost of producing $1 \mathrm{KWh}$ with conventional oil source stood at around Rs. 14.84 (including all cost of production). Of this, about Rs. 3.37 is the cost of furnace oil to produce $1 \mathrm{KWh}$ of electricity. Table 2 presents the substitution of furnace oil with sugar industry bio mass in the long run.

Table-2. Substitution Effect of Sugarcane Energy on Country's Furnace Oil Imports (Long Run)

\begin{tabular}{|c|c|c|c|c|}
\hline \multirow[b]{2}{*}{ Scenarios } & \multirow[b]{2}{*}{$\begin{array}{l}\text { Electricity } \\
\text { Generation }\end{array}$} & \multicolumn{3}{|c|}{ Sugar Crushing Season (100 days) } \\
\hline & & $\begin{array}{c}\text { Cost of Conventional Fuel } \\
\text { in } \$-\text { Off Season } \\
\text { Amount in US } \$\end{array}$ & $\begin{array}{c}\% \text { of Furnace Oil } \\
\text { Imports (100 days) } \\
\%\end{array}$ & $\begin{array}{c}\text { Other Cost } \\
\text { Saving }\end{array}$ \\
\hline $\begin{array}{c}\text { Scenario } 1 \\
\text { Capacity } \\
\text { Utilization @ 60\% } \\
-525 \mathrm{MW} \\
\end{array}$ & 1,260,oooMWh & $42,462,000 \$$ & $4.2 \%$ & $144,522,000 \$$ \\
\hline $\begin{array}{c}\text { Scenario } 2 \\
\text { Capacity } \\
\text { Utilization @ 80\% } \\
\text { - 700 MW }\end{array}$ & 1,680,000MWh & $56,616,000 \$$ & $5.62 \%$ & $192,696,000 \$$ \\
\hline $\begin{array}{c}\text { Scenario } 3 \\
\text { Capacity } \\
\text { Utilization } 100 \%- \\
875 \mathrm{MW}\end{array}$ & 1,750,o0oMWh & $58,975,000 \$$ & $5.86 \%$ & $200,725,000 \$$ \\
\hline $\begin{array}{l}\text { Optimum Capacity } \\
\text { Level (3000 MW) }\end{array}$ & 7,200,000 MWh & $242,640,000 \$$ & $24.1 \%$ & $825,840,000 \$$ \\
\hline
\end{tabular}

Formula: Conventional Cost Saving (Conversion into KWh x3.37)/100;

Other Cost Saving (Conversion into KWh x11.47)/100

Total Cost per KWh electricity generation via Furnace Oil Rs. 14.84 (NEPRA, 2011)

Cost of Conventional Fuel calculated on the basis of Rs. 3.37 per KWh by furnace oil;

Cost of Conventional Fuel calculated on the basis of Rs. 3.37 per KWh by furnace oil
Other cost: Excluding Cost of furnace Oil i.e. Rs. 11.47

Based on discounted 100 days of Generation in relation to $120-160$ operational days

Exchange Rate: 1US\$ = Rs. 100

Optimum capacity is the sugar industry's power generation potential

Calculation year base is 2012-13 
In long run, the industry with other sectors can support in reducing the ever growing oil imports of the country. As shown in the above table, the sector during the crashing season can save at minimum 42 million dollars of foreign exchange that is about 4.2 percent of the total furnace oil import. While at maximum, with the utmost capacity utilization with respect to raw material availability, this foreign exchange savings can increase to 5.86 percent. Lastly, at the optimum capacity of $3000 \mathrm{MW}$ using other biomass including bagasse, the total saving during the season can be stood at 242 million dollars that is about 24 percent of total furnace oil import during the season only. Other than this, during the season the additional cost associated with the generation and supply of electricity is minimal vis-à-vis cost of IPPs.

Efficiency in the sugar industry can be increased by updating the boilers from low pressure boilers to state-ofthe-art high-pressure and high-temperature technology. However, the success of cogeneration schemes depends on maximization and efficient energy output with lower energy consumption for mill operations. ${ }^{38}$ State-of-the-art technology with improved steam conditions could improve the energy efficiency, thus allowing more energy to be exported. ${ }^{39}$

\section{Conclusion, Policy Recommendations and Research Directions}

Pakistan's energy crisis if not tackled at both operating and strategic level in the immediate future might become a national security threat. ${ }^{40}$ This capacity shortfall will significantly impact economic growth in years to come. According to Rashid (2013) on Pakistan's energy sector, country is losing about 2 percent of its GDP due to shortfall in energy supply. ${ }^{41}$

The yawning gap needs to be addressed at earliest and efforts need to be intensified to introduce various alternative sources of energy. The ever increasing demand-supply gap of electricity in country has to be filled with most significant and efficient alternative energy source. There is an urgent need to diversify the energy from traditional sources to renewable energy sources; increase use of wind power, tidal power, and biogas, solar and geothermal energy. ${ }^{42}$

Sugar industry is considered as a potential substitute readily available ensuring economic benefits to the country along with the financial and socio-economic benefits to agro industry and the associated rural population. There are positive environmental consequences in terms of emission of green-house gases. In short run, the sector not only increases the size of the total energy mix but also provides diversification in the supply side. Further there is no additional cost associated with the supply of energy during the off season as compared to IPPs. The off season cost is also expected to be lower due to low and moderate technology vis-à-vis IPPs.

The winter season is termed with the lack of rain and less potential of hydropower due to lowering of water levels. During the season, the industry can support the reduction of load shedding. The industry would also be strategically supportive to the Gas Load Management plan during the peak winter season i.e. from December to February. The Gas load management during the peak winter harm significantly the economic activities due to nonsupply of gas power to major industrial units in the country.

In the long run, the industry along with other renewable energy mix, would reduce the oil import burden thus save precious foreign exchange reserves. As of 2010 , Pakistan ranked $8^{\text {th }}$ in the total import of residual fuel oil accounts for 3.5 percent of the total world residual fuel oil imports. ${ }^{43}$ The import of oil and oil products accounts for almost 33 percent of the total imports. During 2012-13, the share of furnace oil in the total oil imports stood around 29.7 percent in terms of value. ${ }^{44}$

Implementation of cogeneration projects in Pakistan's, sugar industry is definitely one of the major sectors that can enable country to not only diversify its energy base but also rehabilitate and modernize the agro industrial activities. This in turn will have indirect positive impact on agricultural production and employment opportunities in rural areas. There is a need to learn from experiences of other sugarcane producing countries where replication or adaptation of such energy projects considered successfully.

Following are some strategic policy options and recommendations from the study:

1. The initiative of co-power generation from sugar industry would also bring local and foreign investment in the sector. This could augment the initiative to convert the industry's steam boilers to coal or other fuel for enabling them to supply the power for the longer period or whole year.

However, the incentive should be provided for the participation of private capital in joint-venture projects to develop the energy potential of the sugar industry.

2. Low cost power generation would reduce the burden on government subsidy thus would have positive impact on fiscal measures and circular debt.

3. Low cost power generation by sugar industry could be supplied to hospitals, education institutions etc. thus would have positive impact on delivery of basic social services

4. The initiative could also augment the agriculture sector for the increase in production of sugarcane; Pakistan ranked amongst the top five producers of sugarcane in the world, however, in terms of yield per hectare, Pakistan is not found in the top ten high yielded sugarcane producing countries. So, there is need to improve production technologies for higher yield per hectare.

5. Reduction in import bill through reduction in Furnace Oil Imports.

6. Avoiding / reducing long hours load shedding would definitely have positive impact on business, thus would reduce the cost associated with frequent shut downs of production plants and enhance efficiency;

7. Bringing the sugar industry in power generation (co-power generation), supply side of the energy sector would further diversified and bring competitive efficiency with in the sector;

8. Impact of GDP will be substantial. The strategy of alternative energy production would enable the country to minimize the production loses from power load shedding.

9. A separate power policy in the name of SPP (Sugar Power Producer) is highly recommended to accommodate the incentive demand of sugar industry.

This research will open the window for further in-depth research to understand the correlation between agriculture production and yield, the agro-based industrial growth and the capital investment. Second there is a 
need to understand the bio-fuel generation capacity of the industry. The bagasse and SCAR conversion into Bio-oil via fastpyrolysis could be a solution to the problem of its energy storage, allowing it to be used locally as the need arises. Among the main advantages of sugarcane, biomass conversion into a liquid fuel is the storable bio-oil provides an alternative to the total conversion of sugarcane biomass into electricity. However, this is fuel is not considered as a stable fuel. ${ }^{45}$

\section{References}

Abraj Capital, 2006. The infrastructure requirements of the MENASA Region. Retrieved from http://static.wamda.com/web/uploads/resources/MENASA_Region_Infrastructure_Investment_Requirement_Research_Report. pdf.

Akhtar, S., 2011. The potential impacts of coal on electricity generation and economic growth of Pakistan. Far East Journal for Psychology and Business, 2(5): 60 -70. View at Google Scholar

Deepchand, K., 2001. Commerical scale cogeneration of bagasse energy in mauritius. Energy for Sustainable Development, 5(1): 15-22. View at Google Scholar | View at Publisher

Deepchand, K., 2005. Sugar cane bagaase energy cogeneration - lessons from mauritius. Parlimentarian Forum on Energy Legislation and Sustainable Development, Cape Town, South Africa

Energy Technology Centre, 2011. Case study Indonesian sugar industry: Productivity gains from efficient waste to energy schemes. Energy Technology Centre, Agency for the Assessment and Application of Technology.

Gwang'ombe, F.R.D., 2004. Renewable energy technologies in Tanzania: Biomass - based coogeneration. Second Draft Report, Nairobi, Kenya.

Hussain, A.S., 2012. Daily dawn. Retrieved from http://dawn.com/news/746512/mills-for-new-policy-on-bagasse-fuelled-powercogeneration [Accessed October 12, 2013].

Javid, A.Y., M. Javid and Z.A. Awan, 2012. Electricity consumption and economic growth: Evidence from Pakistan. Economics and Business Letters, 1(3): 16-27.

Manzoor, H.M., 2010. Sugar industry: Sector update 2010. JCR-VIS Credit Rating Company Limited. Retrieved from www.jcrvis.com.pk.

Mbohwas, C., 2013. Energy management in the South African sugar industry. Proceedings of the World Congress on Engineering, I.

Mitr Phol Group, 2012. Biomass power: High efficiency boiler technology for sugar industry. Seminar on Renewable Energy Technology Implementation in Thailand.

Mubashir, Q. and K. Koji, 2013. Causes of energy shortage in Pakistan: An empirical evidence. IUJ Research Institute: Economics \& Management Series, EMS-2013-01.

Muhammad, T. and M. Khalid, 2012. Sugar industry: A cheap and easy source of electricity: A case study of District Mandi Bahauddin. Universal Journal of Management and Social Sciences, 2(4): 97-103. View at Google Scholar

National Academy Press, 1986. Electricity in economic growth. A Report Prepared by committee on Electicity in Economic Growth, Energy Engineering Board, Commission on Engineering and Technical Systems and National Research Council, National Academy Press, Washinton.D.C.

Quraishi, M.M., 1984. Renewable sources of energy in Pakistan. Pakistan Development Review, $23(2$ \& 3): 457-472.

Rashid, A., 2013. Building an efficient energy sector, Pakistan Policy Note 1, World Bank, June 2013, No. 79558. Available from wwwwds.worldbank.org/external/default/WDSContentServer/WDSP/IB/2013/07/17/000442464_20130717121 249/Rendered/PDF/795580BRIoSASEoBox0377381BooPUBLICo.pdf.

Saqlain, S.L., H.S. Muhammad, M. Haider and S. Muhammad, 2013. Coal consumption: An alternate energy resource to fuel economic growth in Pakistan. MPRA Paper No. 50147. Retrieved from http://mpra.ub.uni-muenchen.de/50147/.

Shahbaz, M., Z. Muhammad and A. Talat, 2012. Is energy consumption effective to spur economic growth in Pakistan? New evidence from bounds test to level relationships and Granger causality tests. MPRA Paper No. 39734. Retrieved from http://mpra.ub.unimuenchen.de/39734/.

Stern, D.I. and C.J. Cleveland, 2004. Energy and economic growth, rensselaer - working papers in economics, number 0410. Retrieved from http://www.economics.rpi.edu/workingpapers/rpi0410.pdf.

Walfrido, A.-P., L.A. Carlos, F.F. Felix, G. Pietro and C. Giacinto, 2009. Cogernation and bio-oil production starting from sugarcane biomass residues: Barriers, challenges and opportunities. Open Fuels and Energy Science Journal, 2(1): 34-39. View at Google Scholar

Zeeshan, M., 2012. Finding the optimal way of electricity production in Pakistan. MPRA Paper No. 38485 . Retrieved from http://mpra.ub.uni-muenchen.de/38485/.

Ziad, A., 2012. Pakistan's energy sector: From crisis to crisis - breaking the chain. Pide Monograph Series (2012), Pakistan Institute of Development Economics.

Ziad, A., 2012. Report of interactive discussion session on integrated energy policy formulation with emphasis on social dimensions. Social Policy and Development Centre.

\section{Footnote}

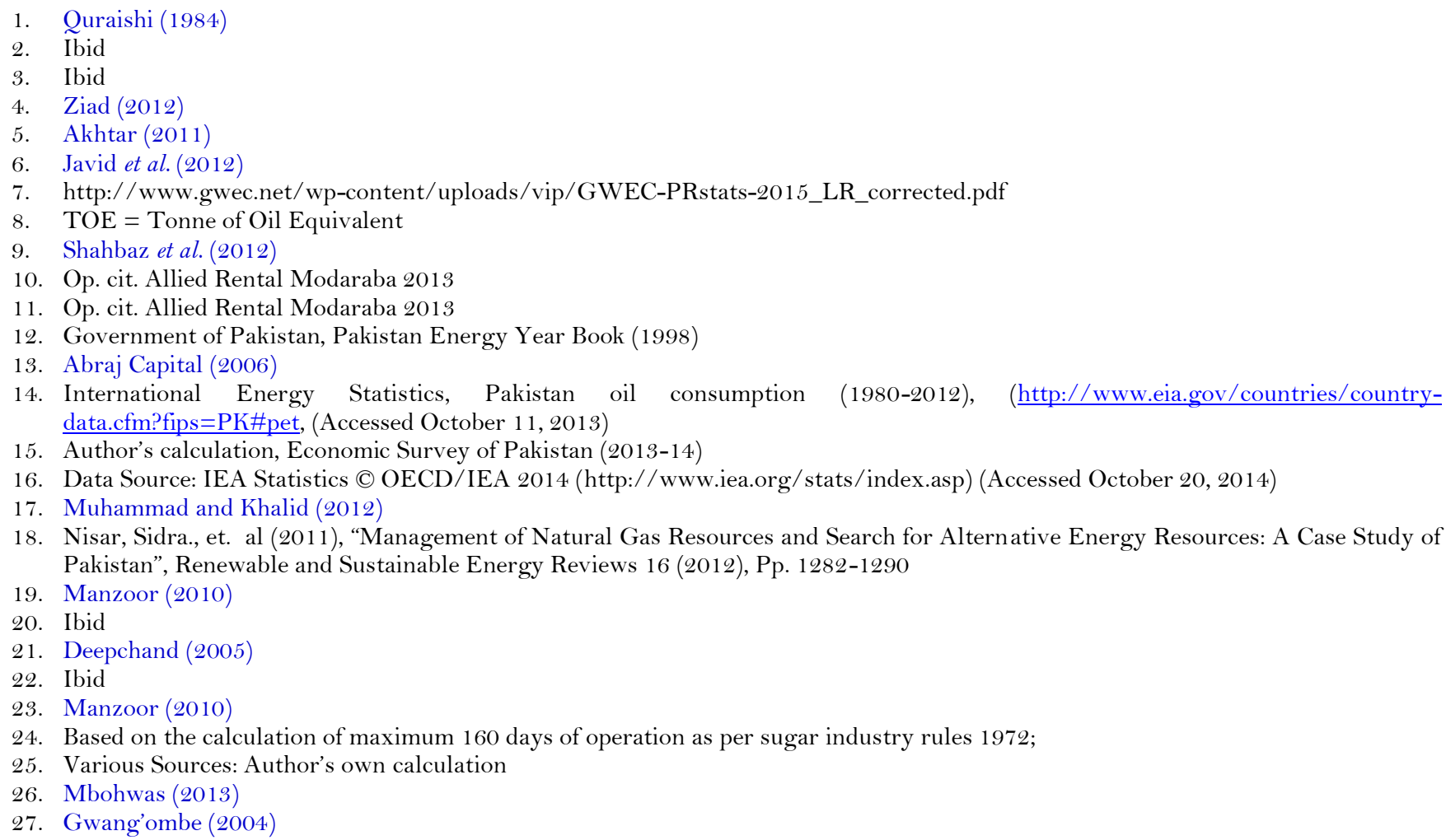

18. Nisar, Sidra., et. al (2011), "Management of Natural Gas Resources and Search for Alternative Energy Resources: A Case Study of Pakistan”, Renewable and Sustainable Energy Reviews 16 (2012), Pp. 1282-1290

19. Manzoor (2010)

20. Ibid

21. Deepchand (2005)

22. Ibid

23. Manzoor (2010)

24. Based on the calculation of maximum 160 days of operation as per sugar industry rules 1972;

25. Various Sources: Author's own calculation

26. Mbohwas (2013)

27. Gwang'ombe (2004) 
28. Deepchand (2005)

29. op. cit., Tahir, Muhammad. (2012)

30. Energy Technology Centre (2011)

31. Anna Austin (January 2011) http://biomassmagazine.com/articles/5247/bagasse-power (Accessed October 19, 2013)

32. Mitr Phol Group (2012)

33. Hussain (2012)

34. Based on discounted 100 days of Generation in relation to $120-160$ operational days

35. Based on discounted 100 days of Generation in relation to $120-160$ operational days.

36. Based on discounted 100 days of Generation in relation to $120-160$ operational days

37. Ziad (2012)

38. Mbohwas (2013)

39. Ibid, P.p 6

40. Op.cit. Allied Rental Modaraba

41. Daily Jang (November 2, 2013)

42. op. cit., Qureshi M. M

43. http://www.factfish.com/statistic-country/pakistan/residual+fuel+oil,+imports (accessed July 2014)

44. Economic Survey of Pakistan 2013-14

45. Walfrido et al. (2009) 